Maxwell, N; (2015) How humanity might avoid devastation. Ethical Record , 120 (1) 18 - 23 Downloaded from UCL Discovery: http://discovery.ucl.ac.uk/1469688

\title{
How Humanity Might Avoid Devastation
}

Nicholas Maxwell, Emeritus Reader, University College London

Ethical Record, vol. 120, no. 1, January 2015, pp. 18-23.

\section{Global Crises}

The future of humanity is threatened by grave global problems. There is the problem of war, over one hundred million people having been killed in countless wars during the course of the twentieth century (which compares unfavourably with the twelve million or so killed in wars during the nineteenth century). And we have not done very well so far in the $21^{\text {st }}$ century. There is the obscenity of the arms trade, the massive stockpiling of armaments, even by poor countries, and the ever present threat of their use by terrorists or in war, whether the arms be conventional, chemical, biological, or nuclear. There is the sustained, profound injustice of immense differences in wealth around the globe, the industrially advanced first world of North America, Europe, and elsewhere experiencing unprecedented wealth while something like a fifth of humanity live in conditions of abject poverty in the third world, hungry, unemployed, without proper housing, health care, education, or even access to safe water. There is the long-standing problem of the rapid growth of the world's population, pronounced especially in the poorest parts of the world, and adversely affecting efforts at development. There is the problem of the progressive destruction of tropical rain forests and other natural habitats, with its concomitant devastating extinction of species. Humanity urgently needs to discover how to create a sustainable world industry and agriculture that does not wreak havoc on the environment; attempts do this have, so far, proved ineffective. There are problems of pollution of air, sea and earth, and problems of depletion of finite resources. And over everything hangs the menace of climate change, threatening to intensify all the other problems - apart, perhaps, from population growth. (As the climate warms, millions will die. They are dying already.)

But it is worse than that. It is not just that our efforts to tackle global problems seem pathetically inadequate. Far worse, much of our efforts seem devoted to intensifying our problems. We know that if we continue to emit carbon dioxide at anything like the rate we do at present, we are heading towards disaster. Does this mean we cut back on emissions? All sorts of measures are introduced, but $\mathrm{CO}_{2}$ emissions actually increase or only fail to increase because of the world economic recession. High up on the agenda of every government of every nation is economic growth; but it is economic growth, as conducted at present, which leads to higher $\mathrm{CO}_{2}$ emissions - even if this need not be if power, industry and transport were run on different, more sustainable lines.

Governments seek security, build up their armies and defence in order to procure security, provoke suspicious neighbour nations to do likewise, and thus increase insecurity and the danger of war.Banks seek wealth, and plunge the world into debt, recession and poverty. 
Progress is eagerly sought, and the outcome is industrial, agricultural and population growth beyond what the planet can support. Natural habitats are destroyed, species annihilated, land and sea polluted.

We seem trapped in a vicious nightmare in which what we strive to achieve, our finest and most passionately sought aspirations and ideals, are transformed, as we draw closer to them, into ugly and dangerous monstrosities, threats to our very existence. What we love the most turns out to do us the most harm.

A key example of this nightmare twist is science. Modern science has been pursued, ever since its birth in the $17^{\text {th }}$ century, with the passionate conviction that science will better the lot of humanity. Unquestionably, science has met with quite astonishing intellectual success in improving our knowledge and understanding of the universe, and ourselves as a part of the universe. And modern science and technology have been of immense benefit to humanity. In countless ways, those of us fortunate to live in the wealthy, industrially advanced parts of the world have had our lives enriched beyond the wildest dreams of people living only a couple of centuries ago. Modern science has made possible the modern world.

At the same time science has helped to create all our current global problems - or at least has made them possible. Science and technology have led to modern industry, agriculture, transport, armaments, medicine and hygiene. And these in turn have led to global warming, population growth, destruction of natural habitats and rapid extinction of species, the development of extreme inequalities of wealth and power around the globe, pollution of earth, sea and air, depletion of natural resources, the lethal character of modern war, the increasing threats posed by the spread of modern armaments.

No wonder many conclude, not just that we cannot make things better, but all our efforts to do so, however nobly and energetically pursued, are doomed just to make things worse. A typical example of someone who thinks along these lines is the very popular writer John Gray who, in book after book, article after article, has argued that progress is illusory, all our efforts to transform the human condition inevitably ending in nightmare. ${ }^{1}$

\section{What Can We Do?}

Is there anything we can do to escape this nightmare of even our noblest efforts to make things better ending up making things worse?

There is. In order to make progress towards a better world we need to learn how to do it. And for that, in turn, we need institutions of learning rationally designed and devoted to helping us learn how to solve our global problems, how to make progress towards a better world. It is just this that we lack at present. Our universities are devoted to the pursuit of knowledge. They are neither designed nor devoted to helping humanity learn how to tackle global problems - problems of living - in more intelligent, humane and effective ways. That is the key disaster of our times, the crisis behind all the others: our failure to have developed our institutions of learning so that they are rationally organized and devoted to helping us solve our problems of living - above all, our global problems. Having universities devoted almost exclusively to the pursuit of knowledge is, as we have seen, a recipe for disaster. Scientific knowledge and technological know-how have unquestionably brought great benefits to humanity. But they have also made possible even caused - our current global crises. ${ }^{2}$ 
Academia, as it exists at present, devoted primarily to the pursuit of knowledge, is the outcome of efforts to create a kind of academic inquiry that is rationally organized and devoted to helping humanity achieve what is of value in life, solve problems of living, make social progress towards as good a world as possible. The idea that the fundamental social or humanitarian goal of rational inquiry should be to better the lot of humanity goes all the way back to Francis Bacon in the $17^{\text {th }}$ century. And Bacon helped inspire many of those who created modern science. His writings were inspirational in the creation of the Royal Society in Britain. Natural science - or natural philosophy, as it was known in the $17^{\text {th }}$ century - was pursued in part in the passionate belief that knowledge acquired would help transform the human condition for the better.

The idea was further developed by the Enlightenment of the $18^{\text {th }}$ century, especially by the philosophes of the French Enlightenment. Voltaire, Diderot, Condorcet and the rest had the fundamental and profound idea that it might be possible to learn from scientific progress how to achieve social progress towards an enlightened world. In developing this immensely important idea, the philosophes took it for granted that, in order to put this idea into practice what one needed to do was to develop the social sciences alongside the natural sciences.

So the philosophes set about creating the social sciences alongside the natural sciences. They brought into existence, or developed, economics, sociology, psychology, anthropology, political science, history, the study of law, culture and custom. What the philosophes initiated or developed in the $18^{\text {th }}$ century, others - such as J .S. Mill and Karl Marx - further developed throughout the $19^{\text {th }}$ century, often outside universities until, in the early $20^{\text {th }}$ century social science was built into academic inquiry in universities all over the world with the creation of departments of social science: economics, sociology, anthropology, psychology, political science.

The outcome is what, by and large, we have today, academic inquiry devoted, in the first instance, to the pursuit of knowledge - or knowledge-inquiry as we may call it. There are two basic ideas inherent in knowledge-inquiry.

(1) The primary task for academic inquiry is to acquire knowledge and technological know-how. First, knowledge must be acquired. Once acquired, it can then be applied to help solve social problems.

(2) In order to be of value to humanity, knowledge must be objective, factual and reliable. This means only those considerations relevant to the assessment of knowledge can enter the intellectual domain of inquiry - evidence, valid argument, experimental results, factual claims, empirically testable theories and the like. Values, ideals, emotions, desires, human hopes and fears, human aspirations, expressions of joy and suffering, policy and political ideas, ideas about how to live - all these must be excluded from the intellectual domain in order to ensure that objective knowledge of fact is obtained. Almost paradoxically, expressions of human aspirations and suffering must be excluded from the intellectual domain, from scientific and scholarly papers, books and lectures, so that objective, factual knowledge is obtained, alone of human value. If this strict censorship is not observed, knowledge will degenerate into mere propaganda and ideology, and will cease to be of real benefit to humanity.

Knowledge-inquiry, as summarized in (1) and (2), dominates the academic enterprise today. Not all academic work accords with the edicts of knowledge-inquiry, and by no 
means all academics agree with these edicts. Knowledge-inquiry is, nevertheless, massively influential. It is the dominant paradigm for academia, the only well-known idea as to what constitutes rational inquiry. It is almost unconsciously taken for granted by most academics. It is important to note that knowledge-inquiry does allow that academia may well discuss the application of knowledge to help solve social problems. Medicine, biology, engineering, geography, sociology, economics, psychology, political science, the study of international affairs, even though primarily concerned to acquire knowledge, all have applications to human life. Departments of public policy, peace, environment, risk, development, global governance do explore social problems and how they are to be solved. Discussion of what may be called "problems of living" is not excluded from academia, but it has only a secondary role, in accordance with (1) and (2). The primary task of academic inquiry is to solve problems of knowledge, not problems of living.

Knowledge-inquiry is, however, an intellectual and humanitarian disaster. It is damagingly irrational in a wholesale, structural way. This is the key disaster of our times. It is the gross, structural irrationality of academia that is, in the long term, responsible for the development of our current global problems, and responsible for our incapacity to solve them.

\section{The New Enlightenment}

It all goes back to blunders made by the $18^{\text {th }}$ century Enlightenment. As I have already said, the philosophes had the magnificent idea that it might be possible to learn from scientific progress how to achieve social progress towards an enlightened world. But in developing and putting this idea into practice, they made disastrous mistakes, and it is from these mistakes, built into the intellectual/intellectual structure of universities today, all over the world, that we still suffer today.

In order to put the Enlightenment idea properly into practice, the following three steps need to be got right.

First, the progress-achieving methods of science need to be correctly identified. Second, these methods need to be correctly generalized so that they become fruitfully applicable to any worthwhile, problematic human endeavour, whatever the aims may be, and not just applicable to the endeavour of improving knowledge. And third, the correctly generalized progress-achieving methods then need to be exploited correctly in the great human endeavour of trying to make social progress towards an enlightened, wise, civilized world.

Unfortunately, the philosophes of the Enlightenment got all three steps wrong. They failed to appreciate that the basic aims of science are profoundly problematic, it being important for science to try to improve its aims and methods as it proceeds. Having failed to capture the progress-achieving methods of science correctly, they naturally failed to generalize them properly, so that they become fruitfully applicable to all worthwhile problematic endeavours, and not just the one endeavour of acquiring knowledge. It is not just in science that basic aims are problematic: this is true $\mathrm{n}$ life too. In life we need to try to improve problematic aims, and associated methods, as we act, as we live.

But most disastrously of all, the philosophes got the third step wrong. They failed completely to try to apply aim-improving methods, generalized from science, to the 
immense and profoundly problematic enterprise of making social progress towards an enlightened, wise world. Instead, they sought to apply a seriously defective conception of scientific method to social science, to the task of making progress towards, not a better world, but to better knowledge of social phenomena. They developed social inquiry, not as social methodology, designed to help humanity achieve what is of value in life, but rather as social science, designed to help academic experts improve knowledge of social phenomena. And it is this ancient blunder, developed throughout the $19^{\text {th }}$ century and built into universities in the early $20^{\text {th }}$ century with the creation of departments of social science, that is responsible for what we have today, knowledgeinquiry, in part responsible for the generation of our global problems.

What do we need to do now, in the second decade of the $21^{\text {st }}$ century, to correct the three blunders of the $18^{\text {th }}$ century Enlightenment?

First, we need to adopt and put into scientific practice a new conception of science which acknowledges the real, highly problematic aims of science. This involves formulating scientific method at what may be called the meta-methodological level. Meta-methods specify how the aims and methods of a specific science - or science as a whole - are to be improved in the light of improving knowledge, and other factors. Science adapts its nature, its aims and methods, to what it finds out about the natural world.

Second, we need to generalize this aim-improving, meta-methodology of science so that it becomes fruitfully applicable to any worthwhile human endeavour with problematic aims, and not just applicable to the one endeavour of improving knowledge. For, of course, it is not just in science that aims can be problematic: this is the case in life too.

Third, and most important, we need to try to get this aim-improving meta-methodology into the immense and profoundly problematic enterprise of making social progress towards an enlightened, wise world. The aim of such an enterprise is notoriously problematic. For all sorts of reasons, what constitutes a good world, an enlightened, wise or civilized world, attainable and genuinely desirable, must be inherently and permanently problematic. Here, above all, it is essential to employ methods - metamethods - which help us improve our aims and make progress when basic aims are problematic.

It is above all our failure to build these aim-improving methods into our social world, into individual, institutional and global life, that is responsible for the generation of our current global problems. Global warming, rapid population growth, destruction of natural habitats and extinction of species, depletion of natural resources, pollution of earth, air and sea, the lethal character of modern war, the spread of modern weaponry, intensification of the gulf between the world's wealthy and poor - all these have arisen because of our failure to improve problematic aims of industry, agriculture, politics, finance, the military, trade, international relations. Even the world credit crunch of 2007 and subsequent world economic difficulties fit this pattern. It is not just that we have failed to build into institutions, social fabric and our way of life aim-improving methods, where aims are inherently problematic. We have not even seen the need to do this. Worse still, we have not even had the idea that this is what we need to do. Academia, instead of struggling hard to get the idea understood and implemented, has been preoccupied with quite a different task: the pursuit of knowledge.

The outcome of correcting the three blunders of the philosophes is a kind of academic enterprise very different from knowledge-inquiry - what, by and large, we have at 
present. It would be a kind of academic enterprise more rigorous than knowledgeinquiry, of greater intellectual integrity and value, and far more effective in helping humanity solve problems of living, and make progress towards a better world. I call this new kind of inquiry wisdom-inquiry. It is what emerges when the basic Enlightenment idea is developed and put into practice correctly, without the disastrous three blunders made by the philosophes.

I repeat: the crisis of our times, the crisis behind all the others, is our failure to have developed a kind of inquiry rationally designed and devoted to helping us solve our problems of living, make progress towards a good, wise, enlightened world - or, at least, towards as good a world as possible. Instead of creating wisdom-inquiry, all we have managed to do is create knowledge-inquiry, a botched version of wisdom inquiry.

It is important to appreciate, however, that academia as it exists today, the outcome, by and large, of putting knowledge-inquiry into practice, is a defective version of what we really need: wisdom-inquiry. The task before us is not to create something entirely new, untested, with nothing more to guide us than an abstract philosophical argument. We do not need to leap into the dark blindfolded, as it were, hoping for the best. Rather, our task is to correct quite definite blunders in the structure of academia that we have inherited from the past - blunders we have failed so far to get properly into focus and so put right. We already possess a kind of inquiry created to help us make progress towards a wise, enlightened world: our problem is that we fail to see that the design is defective, and urgently needs to be put right. 


\section{Notes}

${ }^{1}$ See for example, Gray, J., Heresies: Against Progress and Other Illusions, 2004, Granta Books.

${ }^{2}$ The argument that follows was spelled out in great detail long ago in my book From Knowledge to Wisdom, 1984, Blackwell; 2nd ed., 2007, Pentire Press. See also my The Comprehensibility of the Universe: A New Conception of Science, 1998, Oxford University Press; Is Science Neurotic?, 2004, Imperial College Press; How Universities Can Help Create a Wiser World: The Urgent Need for an Academic Revolution, 2014, Imprint Academic; Global Philosophy: What Philosophy Ought to Be, 2014, Imprint Academic. And see my articles available online at www.ucl.ac.uk/from-knowledge-towisdom and http://discovery.ucl.ac.uk/view/people/ANMAX22.date.html. 